\title{
Prototype Pengembangan Sistem Informasi Koperasi Simpan Pinjam Pada Sekolah XYZ Menggunakan Metode Throwaway Prototyping Development
}

\author{
Dani Anggoro \\ Fakultas Teknologi Informasi, Universitas Budi Luhur \\ Jl. Raya Ciledug, Petukangan Utara, Jakarta Selatan, 12260 \\ Telp: (021) 5853753, Fax : (021) 5853753 \\ E-Mail : dani.anggoro@budiluhur.ac.id
}

\begin{abstract}
Cooperatives as one of the economic activity actors in Indonesia must transform operational activities and management to keep abreast of technology in the current digital era. Operational and management activities at the XYZ School cooperative are currently limited to desktop-based systems. These activities certainly need to be developed following the era of digitalization and current technological developments. Operational time of cooperatives is a major obstacle in savings and loan cooperatives at XYZ School. Operational and management activities in the current technological era should not be limited by time and place, making it easier for cooperative staff members and members in operational activities at the XYZ School savings and loan cooperatives. Based on these conditions, the authors make a prototype research on the Development of a Savings and Loan Cooperative Information System at XYZ Schools Using the Throwaway Prototyping Development Method. Research begins with gathering needs, defining the overall objective of the software, identifying all needs, then designing information systems. The results of the development of analysis and design will be illustrated in the form of UML diagrams and the design of a savings and loan information system screen at the Web-Based XYZ School. With the development of cooperative information systems it can help cooperative staff and members to carry out operational activities without being limited by school operational hours, the information produced is more informative and can be accessed anytime and anywhere.
\end{abstract}

Keywords: Throwaway Prototyping Development, System Development, Savings and Credit Cooperatives, Schools

Abstrak- Koperasi sebagai salah satu pelaku kegiatan ekonomi di Indonesia harus mentransformasi kegiatan operasional dan manajemen mengikuti perkembangan teknologi di era digital saat ini. Kegiatan operasional dan manajemen di koperasi Sekolah XYZ saat ini masih terbatas kepada sistem berbasis desktop. Kegiatan tersebut tentu perlu dikembangkan mengikuti era digitalisasi dan perkembangan teknologi saat ini. Waktu operasional koperasi menjadi kendala utama dalam koperasi simpan pinjam pada Sekolah XYZ. Kegiatan operasional dan manajemen di era teknologi saat ini semestinya tidak terbatas oleh waktu dan tempat sehingga mempermudah pihak staf koperasi maupun anggota dalam kegiatan operasional di koperasi simpan pinjam Sekolah XYZ. Berdasarkan kondisi tersebut maka penulis membuat penelitian Prototype Pengembangan Sistem Informasi Koperasi Simpan Pinjam Pada Sekolah XYZ Menggunakan Metode Throwaway Prototyping Development. Penelitian dimulai dengan pengumpulan kebutuhan, mendefinisikan objektif keseluruhan dari software, mengidentifikasikan segala kebutuhan, kemudian dilakukan perancangan sistem informasi. Hasil dari pengembangan analisa dan rancangan akan digambarkan dalam bentuk diagram-diagram UML dan rancangan layar 
sistem informasi simpan pinjam di Sekolah XYZ Berbasis Web. Dengan pengembangan sistem informasi koperasi ini dapat membatu staf koperasi dan anggota dalam melakukan kegiatan operasional tanapa terbatas oleh jam operasional sekola, informasi yang dihasilkan lebih informatif dan bisa diakses kapanpun dan dimanapun.

Kata kunci: Throwaway Prototyping Development, Pengembangan Sistem, Koperasi Simpan Pinjam, Sekolah

\section{PENDAHULUAN}

Perkembangan teknologi dalam sistem informasi di Indonesia saat ini telah memasuki era digital dimana kemampuan manajemen data yang aman dan tepat harus ditingkatkan. Berbagai usaha baik di perusahaan besar, usaha kecil menengah (UKM) maupun koperasi mentransformasi kegiatan operasional dan manajemen dengan mengikuti perkembangan era teknologi saat ini. Koperasi memiliki fungsi untuk mengembangkan potensi dan kemampuan ekonomi anggotanya dan membantu masyarakat sekitar koperasi sehingga tercipta peningkatan kesejahteraan ekonomi. Salah satu produk koperasi adalah koperasi simpan pinjam. saat ini kegiatan operasional dan manajemen di koperasi Sekolah XYZ masih terbatas kepada sistem berbasis desktop sehingga kegiatan operasional koperasi kurang optimal. Berdasarkan hal tersebut maka penulis membuat penelitian yang berjudul Prototype Pengembangan Sistem Informasi Koperasi Simpan Pinjam Pada Sekolah XYZ Menggunakan Metode Throwaway Prototyping Development. Penelitian ini adalah penelitian lanjutan dari penelitian yang penulis lakukan sebelumnya, berjudul Rancangan Sistem Informasi Koperasi Simpan Pinjam Guru Dan Pegawai Pada Koperasi SMK Manggala Tangerang, seiring berjalannya waktu sistem informasi tersebut perlu dikembangkan untuk mengatasi kendala-kendala yang dihadapi dan menyesuaikan dengan kebutuhan teknologi informasi saat ini.

Berdasarkan penelitian yang dilakukan yang dilakukan, penulis mendapati beberapa masalah yaitu: terbatasnya waktu operasional kegiatan koperasi simpan pinjam di sekolah XYZ, data dan informasi tidak dapat diakses sewaktu-waktu, kurang informatifnya informasi yang dihasilkan. Pada pengembangan penelitian ini, penulis membatasi penelitian pada proses simpan pinjam mulai dari pendaftaran anggota koperasi, transaksi simpanan, transaksi peminjaman, pembayaran angsuran pinjaman, pengambilan simpanan dan pembuatan laporan yang dibutuhkan. Pengguna sistem tidak hanya staf koperasi tapi akan melibatkan lebih dari satu pengguna, calon anggota maupun anggota akan terlibat dalam penggunaan sistem.

\section{METODOLOGI PENELITIAN}

\subsection{Sistem Informasi}

Sistem informasi adalah suatu sistem di dalam suatu organisasi yang mempertemukan kebutuhan pengolahan transaksi harian yang mendukung fungsi operasi organisasi yang bersifat manajerial dengan kegiatan strategi dari suatu organisasi untuk dapat menyediakan laporan-laporan yang diperlukan oleh pihak luar tertentu". [1] 


\subsection{Unified Modelling Leanguage (UML)}

Unified Modelling Language (UML) adalah sebuah bahasa berdasarkan grafik/gambar untuk memvisualisasi, menspesifikasikan, membangun dan pendokumentasian dari sebuah sistem pengembangan software berbasis 00 (Object Oriented) UML tidak hanya merupakan sebuah bahasa pemograman visual saja, namun juga dapat secara langsung dihubungkan ke berbagai bahasa pemograman, seperti JAVA, C++, Visual Basic, atau bahkan dihubungkan secara langsung ke dalam sebuah object-oriented database. Bagitu juga mengenai pendokumentasian dapat dilakukan seperti requirement, arsitektur, desain, source code, project plan, tests, dan prototypes [2].

\subsection{Model Prototyping}

Prototyping model adalah proses pengembangan perangkat lunak yang diawali dengan pengumpulan kebutuhan kebutuhan dari sistem, yang dilanjutkan dengan pembuatan prototipe dan evaluasi dari pengguna. Ada dua pendekatan yang dapat digunakan dalam melakukan prototyping, yaitu throw-away prototyping atau rapid prototyping dan evolutionary prototyping. Pada proses evolutionary prototyping, system dikembangkan tanpa mengetahui spesifikasi sistem yang benar di awal pengembangan atau kebutuhan system yang masih abstrak. Verifikasi terhadap sistem tidak memungkinkan untuk dilakukan karena tidak terdapat spsifikasi. Proses validasi dilakukan dengan mendemonstrasikan kecukupan dari sistem. sedangkan pada proses throw-away prototyping spesifikasi awal dari sistem sudah dapat diketahui di awal, sehingga proses prototyping ini ditujukan untuk mengurangi resiko kebutuhan yang tidak terpenuhi [3]. Tahaptahap proses pembuatan prototype tipe kedua (throwaway prototype) :

a. Tentukan kebutuhan.

Tentukan apa kebutuhan user. Analis system mewawancarai user untuk mendapatkan ide tentang apa yang diinginkan oleh user dari system yang akan dikembangkan.

b. Buat prototype. Analis system bekerja sama dengan ahli komputer yang lain, dengan memanfaatkan satu atau beberapa alat bantu untuk pembuatan prototype, mengembangkan prototype.

c. Evaluasi.

Analis system memperkenalkan prototype kepada user, menuntun user untuk mengenali karakteristik dari prototype. Dari kesempatan uji coba ini, user akan memberikan pendapatnya pada analis sistem. Kalau prototype diterima dilanjutkan ketahap selanjutnya. Kalau ada perbaikan maka langkah berikutnya adalah mengulangi tahap1, 2 dan 3 dengan pengertianyang lebih baik tentang apa yang diinginkan oleh user

\subsection{Kajian Pustaka}

Studi dan penelitian mengenai data Sistem Informasi pada Koperasi Simpan Pinjam telah dilakukan oleh beberapa peneliti, diantaranya sebagai berikut:

a. Dani Anggoro: Koperasi Guru dan Pegawai pada SMK Manggala Tangerang sebagai tempat studi kasus merupakan salah satu koperasi yang menyediakan produk koperasi simpan pinjam. Namun, kegiatan tersebut masih dilakukan 
secara manual atau belum terkomputerisasi sehingga menimbulkan masalah dalam input. Metodelogi penelitian adalah berorintasi pada objek dengan mengumpulkan data melalui observasi, wawancara, studi kepustakaan dan dokumentasi. Hasi dari pembahasan ditampilkan dalam bentuk diagram UML dengan aplikasi berbasis desktop menggunakan bahasa pemograman VB.Net dan staf koperasi sebagai pengguna utama. [4]

b. Duwi Cahya Putri Buani: Koperasi Simpan Pinjam SMK 18 LPPM RI Sidareja masih menggunakan sistem yang manual dimana semua pencatatan masih menggunakan buku. Metode pengembangan perangkat lunak yang digunakan dalam penelitian ini adalah metode waterfal dimana hal ini menggambarkan pendekatan yang sistematis dan juga berurutan pada pengembangan perangkat lunak. Hasil dan pembahasan ditampilkan dalam diagram-diagram UML. Aplikasi berbasis desktop dengan bahasa pemograman Java dan staf koperasi sebagai pengguna utama [5].

c. Nurlaila Hasyim[6]: Koperasi Warga Baru MTS N 17 Jakarta dalam kegiatan operasionalnya dilakukan (input) di Microsoft Excel. Informasi tentang sisa tagihan pembayaran data dan koperasi yang diterima oleh anggota hanya dapat diketahui jika para anggota datang langsung ke manajemen koperasi. Metode Pengembangan Sistem yang digunakan adalah metode Berorientasi Objek (Object Oriented) melalui model Rapid Aplication Development (RAD). Pengembangan sistem yang peneliti lakukan menggunakan tiga tahap siklus pengembangan model R. Hasil dari penelitian adalah rancangan sistem koperasi simpan pinjam berbasis web. Pengguan sistem ini adalah anggota dan admin koperasi [3].

\section{HASIL DAN PEMBAHASAN}

\subsection{Analisa Kebutuhan Sistem}

Pada Koperasi Simpan Pinjam di Sekolah XYZ, kegiatan operasional dan majemen menggunakan sistem informasi berbasis desktop dan masih menggunakan media kertas sebagai keluaran sistem. Transaksi dari pendaftaran, pengajuan pinjaman, angsuran pinjaman, pengajuan simpanan sampai pembuatan laporan hanya dilakukan ditempat dan dengan waktu yang terbatas di sekolah. Anggota yang ingin mengetahui status pinjaman dan jumlah angsurnya harus datang ke koperasi. kemudian staf koperasi mengeceknya secara manual. Proses tersebut tentunya tidak efisien dan fleksibel.

\subsection{Analisa Permasalahan}

a. Pada Koperasi Simpan Pinjam di Sekolah XYZ menggunakan sistem informasi desktop sehingga akases informasi yang terbatas kepada staf koperasi.

b. Dikarenakan waktu operasional kopereasi pada Sekolah XYZ yang terbatas, maka anggota koperasi tidak dapat melakukan kegiatan transaksi di koperasi sewaktu-waktu.

c. Segala kegiatan operasional koperasi harus melibatkan staf koperasi, calon anggota maupun anggota kurang terlibat langsung dalam pengggunaan sistem informasi saat ini. 


\subsection{Analisa Kebutuhan}

Permasalahan yang muncul dari analisa sistem yang berjalan pada koperasi di Sekolah XYZ, membuat pihak koperasi ingin mengembangkan sistem informasi yang berjalan sekarang dengan sistem informasi yang baru sebegai berikut:

a. Pendaftaran Anggota

Dalam sistem yang baru ini, untuk melakukan pendaftaran anggota calon anggota cukup mengujungi website koperasi kemudian melakukan pendaftaran online.

b. Peminjaman

Proses peminjaman bisa dilakukan secara online, proses pengajuan pinjaman tidak perlu datang ke koperasi sekolah, sistem mengecek status peminjaman, apabila ada pengajuan yang masuk staf koperasi akan mendapatkan pesan untuk selanjutnya pengajuan di proses oleh staf koperasi

c. Angsuran Pinjaman

Angsuran bisa dilakukan secara transfer bank maupun bayar langsung dikoperasi, anggota melakukan konfirmasi pembayaran angsuran melalui sistem dengan menggungah bukti transfer

d. Simpanan

Proses simpanan dilakukan secara online melalui website koperasi, setoran simpanan dilakukan melalui transfer bank dan menguplodnya m melalui sistem

e. Pengambilan Simpanan

Pengambilan simpanan tidak perlu datang ke koperasi, anggota bisa mengajukan pinjaman melalui fasilitas yang ada di website koperasi, sistem akan mengecek jumlah uang yang bisa diambil. uang akan ditransfer ke rekening anggota yang terdaftar.

f. Perancangan Sistem(Prototipe)

Perancangan sistem bertujuan untuk memberikan gambaran yang jelas sesuai dengan kebutuhan user. Perancangan sistem dilakukan apabila tahap dari analisis kebutuhan sistem telah selesai dilakukan.

\subsection{Bahasa Pemograman}

Bahasa pemograman yang digunakan adalah PHP, menggunakan Framework Codeigniter 4.0, dengan dasar pertimbangan sebagai berikut:

a. Mempercepat dan mempermudah pembangunan aplikasi web

b. Relatif memudahkan dalam proses maintenance karena sudah ada pola tertentu dalam sebuah framework

c. Framework sudah menyediakan fasilitas yang umum dipakai seperti validasi, pegination, multiple database, error handling dan lain-lain.

d. Lebih mudah dalam pengembangan

\subsection{Proses Bisnis Usulan}

a. Pendaftaran Anggota

Calon anggota mengunjungi website koperasi Sekolah XYZ, pilih menu pendaftaran, unduh Formulir Pendafataran Online, kemudian mengisi form pendaftaran dan mengupload berkas pendafataran KTP dan Formulir 
Pendafataran Online yang sudah di tandatangani. Sistem mengirimkan pemberitahuan ke staf koperasi melalui E-Mail, Staf Koperasi membuka website koperasi Sekolah XYZ, melalukan login, memverifikasi dan memvalidasi data pendafataran, jika diterima sistem akan mengirimkan E-Mail pemberitahun ke calon anggota. Calon anggota membayar simpanan wajib melaui Transfer Bank dan menguplod bukti transfer melalui website. Staf koperasi mengecek kesesuaian bukti transfer dengan mutasi rekening, jika sesuai calon anggota mendapatkan User dan Password login yang dikirim memalui E-Mail. Setelah berhasil login anggota melengkapi profil anggota kemudian mencetak kartu anggota dan bisa melalukan transaksi lainnya.

b. Pengajuan Peminjaman

Anggota login ke website koperasi Sekolah XYZ, pilih menu pengajuan pinjaman, isi form peminjaman (jumlah pinjam, lama pinjman, keperluan dan lain-lain), sistem mengecek pernah mengajukan dan belum lunas, jika sudah lunas atau tidak ada pinjaman sistem mengirim pesan pemberitahuan ke staf koperasi melalui email. Staf koperasi melakukan validasi pinjaman, status pinjaman (disetujui/ tidak disetujui)akan tampil di halaman website anggota koperasi, jika disetujui maka anggota diminta untuk mengunduh formulir persetujuan pinjaman kemudian mendatatangani. Formulir yang sudah di tandatangani diunggah melalui fasilitas yang ada di website koperasi. Jika dokumen valid, uang akan di transfer di rekening anggota, kemudian staf koperasi mengirimkan bukti transfer melalui fasilitas konfirmasi Transfer.

c. Angsuran Pinjaman

Setiap bulan, sistem akan mengirimkan tagihan angsuran yang harus dibayarkan oleh anggota, anggota dapat melakukan pembayaran tagihan melalui bank transfer atau pembayaran langsung ke staf koperasi. setelah melakukan pembayaran anggota login ke website koperasi Sekolah XYZ dan melakukan konfirmasi pembayaran melalui website tersebut. Staf koperasi mengecek kesesuaian pembayaran dengan konfirmasi pembayaran anggota jika sesuai status pembayaran diubah menjadi lunas.

d. Pengajuan Simpanan

e. Anggota dapat melakukan pengajuan simpanan sukarela dengan login ke website kemudian mengisi form simpanan, pilih jenis simpanan kemudian melakukan pembayaran, pembayaran dapat dilakukan melalui transfer bank, jika sudah ditransfer anggota melakukan konfirmasi dengan mengunggah bukti transfer di menu konfirmasi transfer. Staf koperasi mengecek keseuaian pembayaran dengan konfirmasi pembayaran jika sesuai saldo simpanan akan bertambah.

f. Penarikan Simpanan

Anggota login ke website koperasi Sekolah XYZ, pilih menu pengajuan penarikan simpanan, isi form penarikan simpanan pilih jenis simpanan yang akan ditarik, staf koperasi akan menerima pemberitahuan penarikan yang dilakukan anggota. Jika disetujui anggota harus mendowlod Formulir Persetujuan Penarikan kemudian menandatanganinya untuk selanjutnya di unggah, jika dokumen valid uang akan ditransfer ke rekening anggota.

g. Laporan 
Anggota dan staf koperasi login ke website koperasi, memilih laporan yang diinginkan, laporan dibagi menjadi laporan pinjaman, laporan angsuran, laporan simpanan dan laporan penarikan simpanan yang ditampilkan dalam bentuk tabel.

\subsection{Interaksi Pengguna dan Sistem}

Interaksi antara pengguna dan sistem digambarkan dalam bentuk diagram use case.

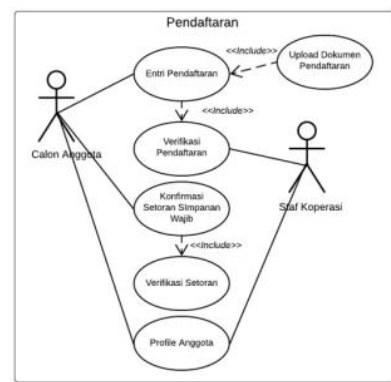

Gambar 1. Use Case Model Pendaftaran Anggota

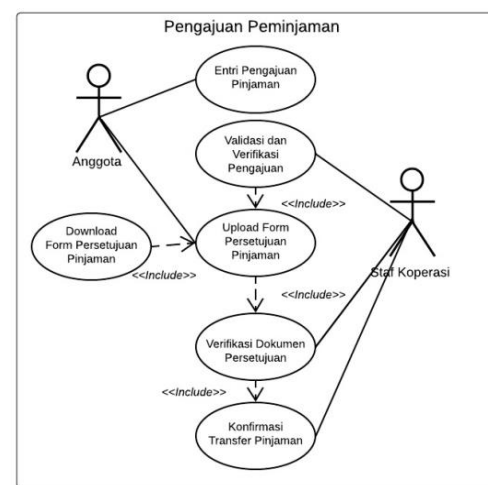

Gambar 2. Use Case Model Pengajuan Pinjaman

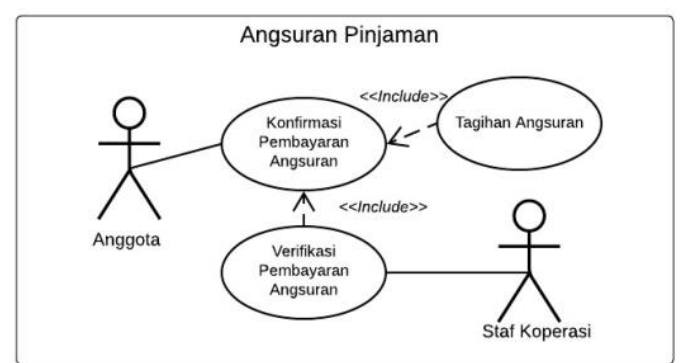

Gambar 3. Use Case Model Angsuran Pinjaman

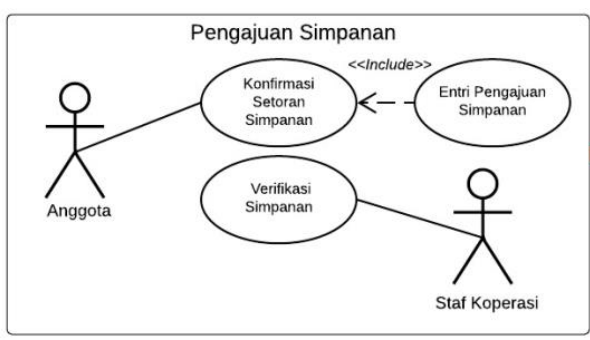

Gambar 4. Use Case Model Pengajuan Simpanan

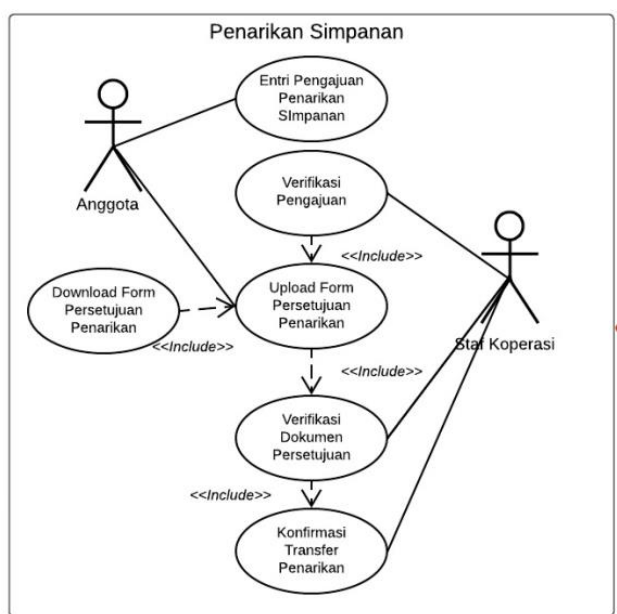

Gambar 5. Use Case Model

Penarikan Simpanan

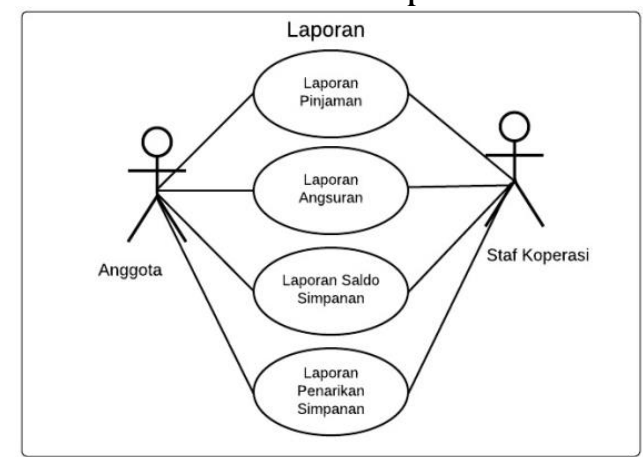

Gambar 6. Use Case Model Laporan 


\subsection{Struktur Tampilan}

Hasil pengembangan sistem Informasi Koperasi Simpan Pinjam Berbasis Web pada Sekolah XYZ masih berupa prototype yang akan dikenalkan dan diuji coba oleh staf koperasi di Sekolah XYZ. Setelah menganalisa kebutuhan dan merancang sistem maka dibuatlah tampilan layar sebagai berikut:

a. Form Login

Sebelum mengakses sistem ini, pengguna harus melakukan proses login terlebih dahulu untuk autentikasi pengguna. Pengguna sebagai staf koperasi atau sebagai anggota koperasi. di form login pengguna diminta user dan password yang terdaftar, jika belum terdaftar pengguna dapat melakukan pendaftaran dengan memilih Daftar. Tampilan form login dapat dilihat dibawah ini:

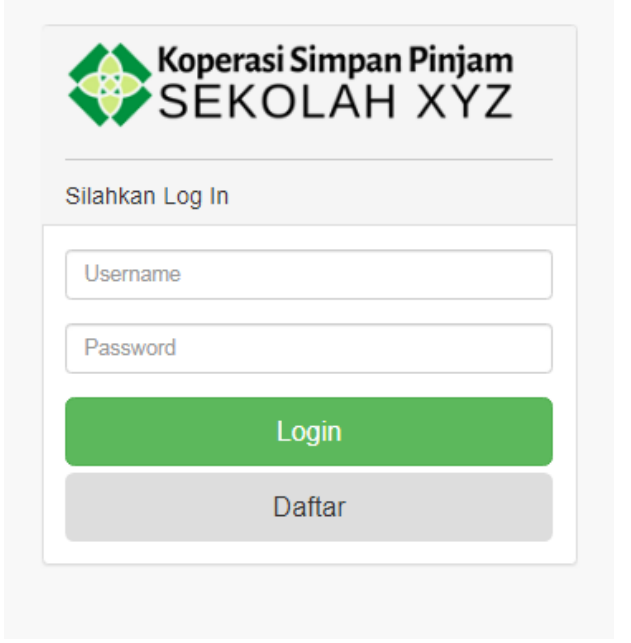

Gambar 7. Halaman Login

b. Dasboard Staf Koperasi

Setelah melakukan login, jika pengguna adalah staf koperasi maka akan dihadapkan dengan halaman dibawah ini. Pada tampilan awal pengguna dihadapkan dengan dasboard informasi pengajuan yang harus di verifikasi. Terdapat halaman menu yang dapat diakses oleh pengguna, menu master data anggota, master data simpanan, transaksi verifikasi pengajuan, verifikasi pembayaran, konfirmasi transfer sampai laporan yang dibutuhkan. 


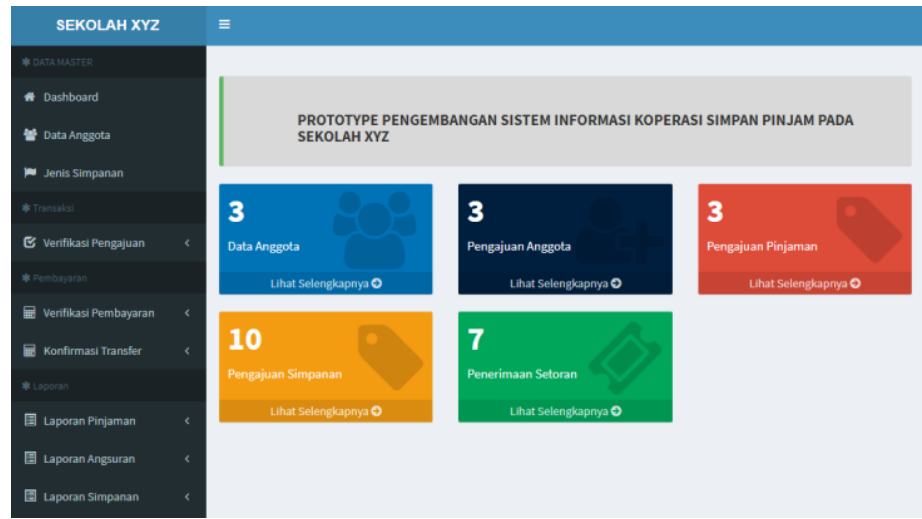

Gambar 8. Halaman Dashboard Staf

c. Form Data Anggota

Form data anggota adalah form yang menampilkan data anggota secara keseluruhan. Pada form ini staf koperasi dapat melihat detail data anggota, mengubah dan menonaktifkan data anggota koperasi. Form ini juga dilengkapi dengan fasilitas pencarian dan penggurutan data yang ingin ditampilkan.

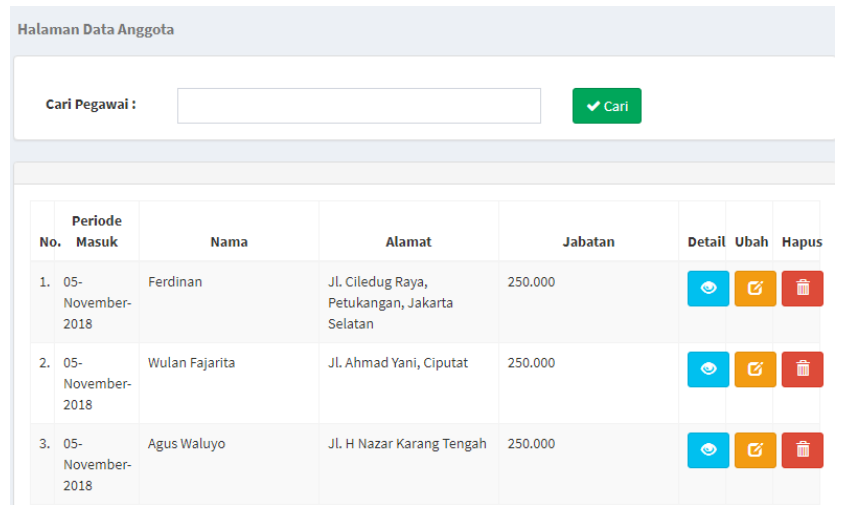

Gambar 9. Form Data Anggota

d. Form Verifikasi

Form verifikasi digunakan oleh staf koperasi dalam memverifikasi pengajuan yang diajukan oleh anggota (verifikasi calon anggota, verifikasi pengajuan pinjaman, verifikasi pengajuan penarikan). Pada form ini staf koperasi dapat memilih pengajuan yang akan diverifikasi kemudian melakukan verifikasi. Terdapat fitur tindakan yang dapat digunakan untuk melihat dokumen yang diupload oleh anggota dan melihat detail data pengajuan. 


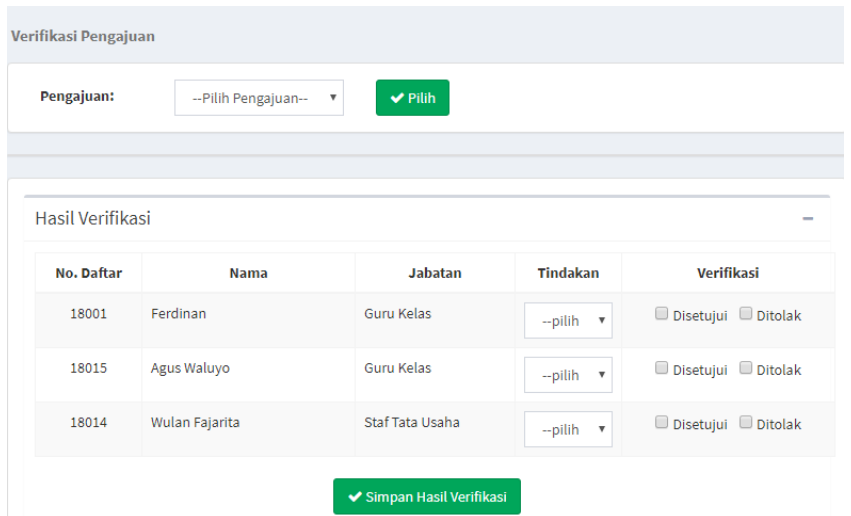

Gambar 10. Form Verifikasi

e. Form Penerimaan Setoran

Form penerimaan setoran digunakan untuk memverifikasi setoran angsuran ataupun setoran simpanan. Staf koperasi dapat memilih jenis setoran yang dilakukan oleh anggota kemudian melalukan verifikasi. Pada form ini juga disediakan tindakan untuk melihat detail informasi setoran dan melihat dokumen yang diupload oleh anggota.

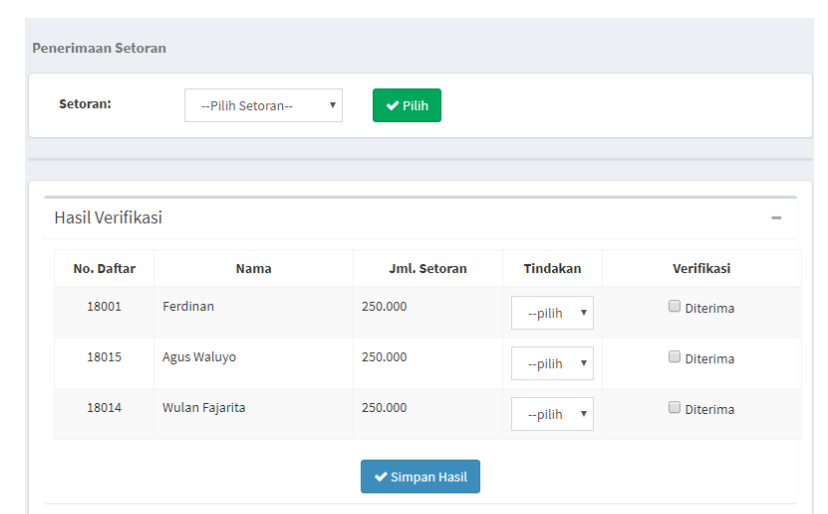

Gambar 11. Form Penarikan Setoran

f. Form Konfirmasi Transfer

Form konfirmasi transfer digunakan oleh staf koperasi untuk mengirimkan konfirmasi transfer ke rekening anggota baik transfer pinjaman maupun transfer penarikan yang diajukan oleh anggota. 


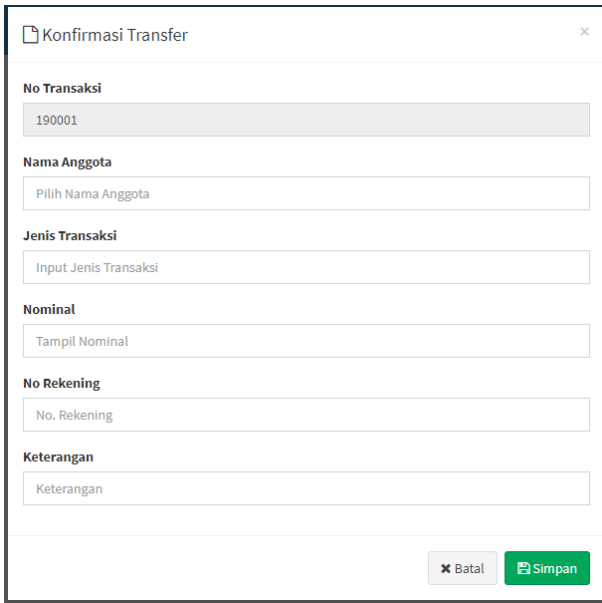

Gambar 12. Form Penarikan Setoran

g. Dashboard Anggota Koperasi

Setelah melakukan login, jika pengguna adalah anggota maka akan dihadapkan dengan halaman dibawah ini. Pada tampilan awal pengguna dihadapkan dengan dasboard informasi saldo simpanan dan pinjaman. Terdapat halaman menu yang dapat diakses oleh pengguna.

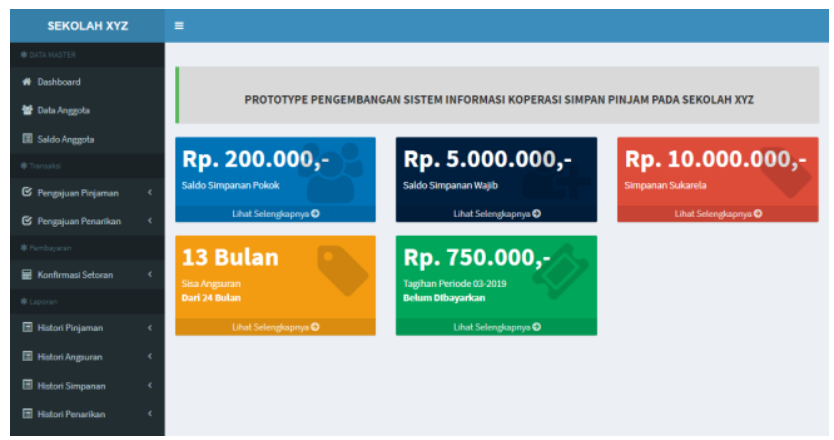

Gambar 13. Form Penarikan Setoran

h. Pengajuan Pinjaman

Form pinjaman digunakan oleh anggota mengajukan pinjaman, dalam form ini pengguna diminta untuk melampirkan file sebelum mengajukan pinjaman.

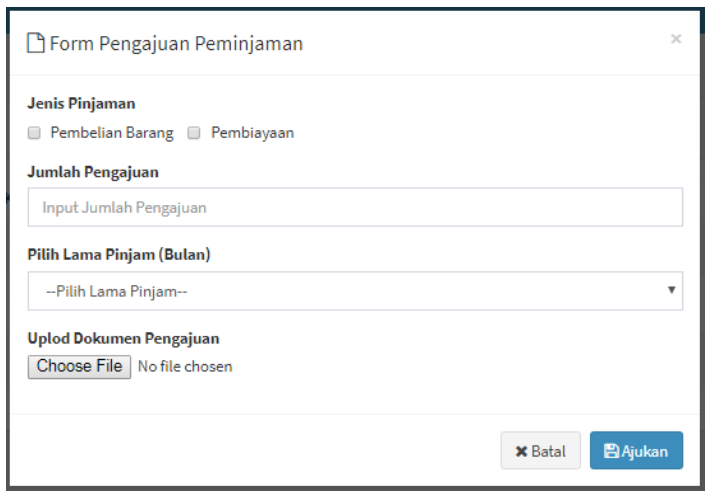

Gambar 14. Form Pengajuan Pinjaman

Prototype Pengembangan Sistem Informasi Koperasi Simpan (Dani Anggoro) | 44 
i. Penarikan Simpanan

Form penarikan digunakan oleh anggota mengajukan penarikan simapanan, dalam form ini pengguna diminta untuk melampirkan file sebelum mengajukan simpanan.

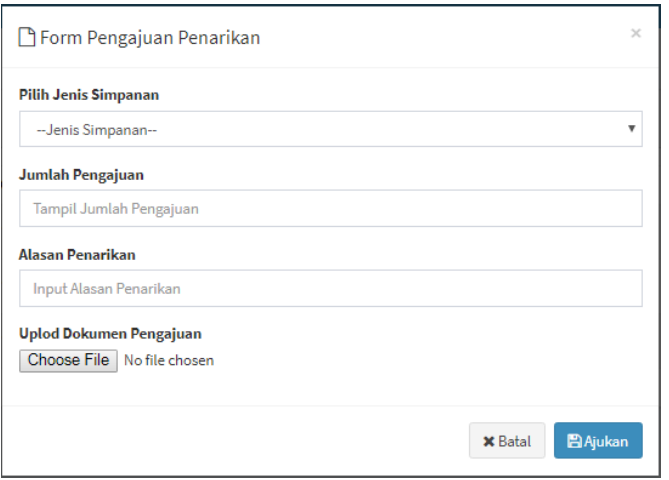

Gambar 15. Form Pengajuan Penarikan

j. Konfirmasi Setoran

Form konfirmasi digunakan oleh untuk konfirmasi setoran baik setoran angsuran maupun setoran simpanan.

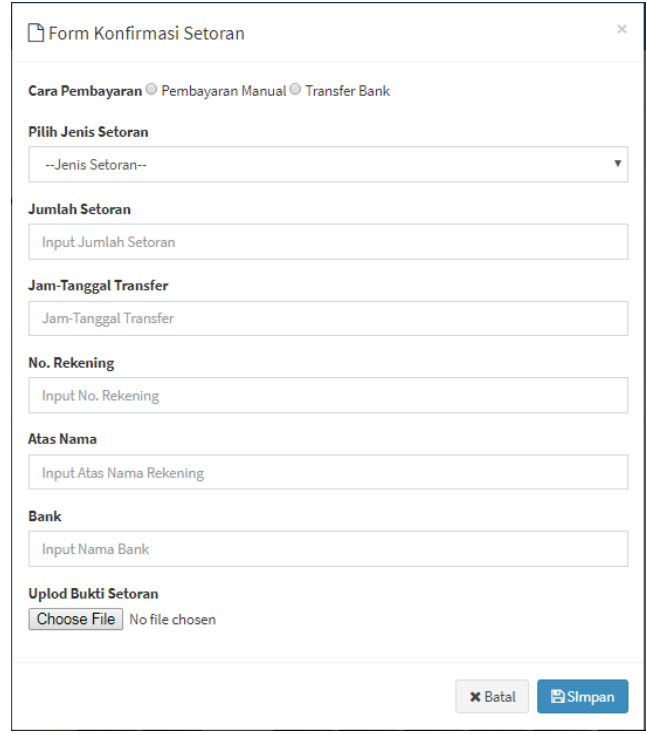

Gambar 16. Form Konfirmasi

\section{KESIMPULAN}

Dari hasil pengembangan Sistem Informasi Koperasi Simpan Pinjam Berbasis Web Pada Sekolah XYZ Menggunakan Metode Throwaway Prototyping Development dapat ditarik kesimpulan sebagai berikut

a. Staf koperasi dan anggota dapat melakukan kegiatan operasional koperasi tanpa terbatas oleh jam sekolah. 
b. Anggota dapat memperoleh informasi lebih informatif, informasi bisa diperoleh melalui web koperasi yang dapat dikases kapan saja dan dimana saja.

c. Dengan metode throwaway prototyping development, sistem dapat dibangun secara terstruktur dan dapat dilakukan tahap pengujian dan pengembangan prototipe lebih lanjut jika dibutuhkan

d. Dengan metode throwaway prototyping development, sistem dibangun sesuai dengan kebutuhan pengguna

e. Pengambangan sistem ini masih dalam bentuk prototipe, dibutuhkan penelitian lanjutan untuk mengimplemntasikan sistem dan pengujian sistem.

\section{DAFTAR PUSTAKA}

[1] Sutabri, T. (2017). Analisis Sistem Informas. Yogyakarta: CV Andi Offset

[2] Dharwiyanti, S. (2003). Pengantar Unified Modeling Language (UML). IlmuKomputer.

[3] Meilantika, D. (2017). Rancang Bangun Sistem Informasi Administrasi Menggunakan Metode Throwaway Prototyping Development Pada Sultan-Sport. Jurnal Teknik Informatika Musirawas, 114-121.

[4] Anggoro, D., David Umar, M., Vinanty, E., \& Dananjaya, D. (2015). Rancangan Sistem Informasi Koperasi Simpan Pinjam Guru dan Pegawai Pada Koperasi SMK Manggala Tangerang. Seminar Nasional Teknologi Informasi dan Komunikasi 2015 (p. 213). Yogyakarta: SENTIKA 2015

[5] Buani, D. C. (2017). Perancangan Sistem Informasi Koperasi Simpan Pinjam Studi Kasus: Koperasi SMK 18 LPPM RI Sidareja Cilacap. Jurnal Ilmu Pengetahuan dan Teknologi Komputer (JITK), 133-138.

[6] Anggoro, D., David Umar, M., Vinanty, E., \& Dananjaya, D. (2015). Rancangan Sistem Informasi Koperasi Simpan Pinjam Guru dan Pegawai Pada Koperasi SMK Manggala Tangerang. Seminar Nasional Teknologi Informasi dan Komunikasi 2015 (p. 213). Yogyakarta: SENTIKA 2015 